\title{
RUTGERS AND THE CIVIL WAR
}

BY RICHARD P. MCCORMICK

I

$\mathrm{T}$ was Saturday when the news of the firing on Fort Sumter reached New Brunswick. Throughout the day excited throngs of citizens gathered at the railroad depot to await the arrival of trains from New York bearing the latest reports on the crisis. Everywhere there was but one topic of conversation and, momentarily at least, such an outpouring of patriotic fervor as never had been witnessed before in the city. On Monday virtually all business activity was suspended as people gathered in animated groups to discuss the President's call for troops. By the end of the momentous week, the conflict had been made real by the passage through the city of General Benjamin F. Butler and the 3rd Regiment of Massachusetts Volunteers and the noted New York 7 th Regiment. Too, a recruiting office had been opened in Greer's Hall, where young men vied with one another in the rush to join the colors.

On Monday evening, April 22, what was hailed as the "greatest popular demonstration" ever held in New Brunswick took place at the First Reformed Church. Addressing an enthusiastic assemblage of townsmen were a dozen of the leading men of the community, including the Rev. Dr. William H. Campbell, the Rev. Dr. Howard Crosby, the Rev. David Cole, and the Rev. Dr. John Proudfit, all of them at sometime members of the faculty of Rutgers College. A few days later, on April 26, the local militia company-the "National Rifles"-was ordered to service and was soon on the way to Virginia.

Meanwhile, all was quiet at the College. On April I2, the day of the bombardment of Sumter, classes had been suspended for the Spring recess, not to be resumed until May I. With a faculty of six professors, the venerable and distinguished Theodore Frelinghuysen as president, and a peak enrollment of I 24 students, the College was in a flourishing condition. Old Queen's, Van Nest Hall, and the President's House provided physical facilities that were adequate, if not grand, and a solid tradition of learning-now almost a century old - gave dignity and character to the institution.

As the students returned to the campus, they were at once caught 
up in the excitement of the times. Heated political discussions and talk of enlistments all but disrupted the prescribed academic routine. The two Texans in the College, J. Greenville McNeel, '62, and his brother, Pleasant D. McNeel, '64, were made to feel so uncomfortable that they soon departed to enter the Confederate service, joining their older brother, George W. McNeel, '6o. All three subsequently gave their lives for the "Lost Cause." Andrew B. S. Moseley, '6 $\mathrm{I}$, departed before commencement to enlist in an Alabama regiment, but according to tradition he was given a special examination and was awarded his diploma at the railroad depot.

In response to the President's call on May third for additional troops to serve for a term of three years, several undergraduates joined with local townsmen to organize a company that was called the "Olden Guards," in honor of Charles S. Olden, the Governor of New Jersey. Absenting themselves from classes, they devoted their time to recruiting and drilling and to waiting for the uniforms that were being made for them by the patriotic women of the city. For these ardent young men, all thoughts of studies had been replaced by the eager hope that their unit would be among the fortunate ones called into service in time to suppress the Rebellion.

Patriotic enthusiasm on the campus reached its climax on May I3. On that day the faculty, student body, and several hundred local citizens gathered in front of Old Queen's to witness the presentation to the College of a large and handsome flag made by the ladies of New Brunswick. A huge pole, extending forty feet above the front of the building had been set in place, and a large platform had been erected to accommodate the distinguished guests and those who were to address the assemblage. Writing of the event many years later, one who had been present as a student remembered it as an exceedingly lively occasion, comparable to a modern football "pep rally." As the crowd gathered, the college boys kept them entertained with songs and jokes. Some even undertook to make speeches, but the cat-calls and applause were so deafening that not a word could be heard.

The formal program began with an inspiring oration by President Frelinghuysen who alternately stirred the crowd to laughter and applause by his vigorous denunciation of secession. Then Garnet B. Adrain, '33, former Congressman and civic leader, presented the 
flag in behalf of the modest ladies. In his remarks, he "congratulated the students that so many of them had determined to go off soon to fight under this banner," a sentiment that was greeted with three hearty cheers. As President Frelinghuysen hoisted the new flag, "the female part of the audience waved their handkerchiefs, while the sterner sex hurrahed." The response on the part of the students was made by the fiery Professor Marshall Henshaw, who pledged "never to suffer these colors to come down in disgrace and dishonor before the assaults of traitors."

As successive speakers stirred the audience to a frenzy of patriotic ardor, President Frelinghuysen was moved to rise and declare: "From all I can see and hear and feel at present, I think I can inform Gov. Olden, when he wants more soldiers, that he can have one hundred able-bodied and able throated men from Rutgers College on one day's notice." This rousing statement was greeted with cries of "Yes, sir," "Good," "That's so," succeeded by three times three cheers and loud calls for additional speakers. Professors Howard Crosby, George H. Cook, and John Forsythe all obliged with appropriate remarks, and a trio of students led in the singing of patriotic songs, after which the crowd dispersed in high spirits. The men of Rutgers had taken their stand.

Several days later, on May 22, there was a second flag presentation. The Olden Guards had been accepted for service as Company G, Ist Regiment, Ist Brigade, N. J. Volunteers, and two thousand citizens gathered in Schureman Street, between George and Neilson, to see the company receive its flag, which had been made by the ladies of Schureman Street. After the impressive ceremonies, the Guards, with martial music, paraded back to their quarters behind their new colors. On the following day the whole city turned out to bid the troops farewell as they boarded the train for Trenton. Scores of firemen, attired in their distinctive red shirts, accompanied the soldiers to the state capital, and for more than a mile out of town the tracks were lined with men, women, and children, all waving handkerchiefs and hats to salute the young defenders of the Union.

Among those riding off to war were eight Rutgers undergraduates: Robert A. Johnson, '6r, Francis S. Keese, Nicholas W. Meserole, George Seibert, and N. Hixon Van Arsdale, all '62; William Henry Pohlman, '63; and John Dooly and John S. Bliss, 
both '64. After a brief stay at Camp Olden, in Trenton, they moved on to Virginia, arriving in time to participate in the disaster of First Bull Run. Most of them fought throughout the war. William Henry Pohlman died of wounds received while commanding his regiment at Gettysburg.

These were not the only Rutgers men to respond to the President's call. William H. H. Ayars, '62, and Thomas L. Stringer, '64, both entered the service as soon as the academic year ended; Ayars joined the 5th Kentucky Volunteers and Stringer the Navy. Ernest L. Kinney waited until he had received his degree before accepting a commission with a New York regiment. Altogether, by July, I 86I, eleven Rutgers men had gone from the campus into the Union forces; three others were fighting for the Confederacy.

By the time the College reopened late in September, I86I, the intense excitement that had characterized the period between Sumter and Bull Run had subsided. The College settled into a quiet routine, seemingly remote from the terrible holocaust. Although enrollments fell sharply-from I 24 in I86I to I05 a year later and then dropped in succeeding years to 79 and 64 - the decline was caused less by the departure of students for military service than by a severe reduction in the numbers of entering students. Only eight undergraduates left college to enter the army during the remainder of the war; with them went one graduate from each of the classes of I 863, I 864, and I 865. Of those who interrupted their college careers to fight for the Union only one-Isaac P. Brokawreturned to Rutgers. Brokaw was readmitted in September, I 864, and received his degree in $\mathrm{I} 866$.

For the students who remained on the campus, college life continued in the familiar pattern. The two literary societies-Philoclean and Peithessophian - met regularly to debate such remote subjects as: "Which is most effective, vocal or instrumental music?" or "Has a society a right to deprive a man of property which he has acquired by fraud?" In their more exuberant moments the undergraduates indulged in calliathumpian serenades, night rioting, and similar escapades. President Frelinghuysen died April I2, I862, and was succeeded by the Rev. Dr. William H. Campbell. New men took the place of old on the faculty: David Murray, T. Sanford Doolittle, David Cole, and Cornelius Crispell. 
Only occasionally did the war intrude upon the routine of the institution. A minor issue arose when the Board of Trustees, meeting at commencement time in 1862 , voted to award "the degree of A.B. (ex gratia)" to the five members of the class of 1862 who had enlisted in the spring of $\mathrm{I} 86 \mathrm{I}$. The faculty resolved that they did "not object to conferring honorary degrees" on the men in question. The Board, doubtless puzzled by this unencouraging response from the faculty, at first referred the matter to a committee, but when the commencement was held, the five soldiers of ' 62 were awarded their degrees, ex gratia. Three years later the same men were in due course awarded, ex gratia, the degree of A.M. In no other instances did men who went into service before graduating receive their degrees.

In May, I 864, when Senior Andrew Doremus requested permission to be absent from commencement in order to join the Sanitary Corps, the faculty set forth three reasons for denying the request. The Senior class was so small-eleven in all_- "that justice to them required that he be present." They also pointed out that "Mr. Doremus could make as much money or more by other means as by this, without the same exposure and danger, and hence pecuniary considerations did not demand his going." Finally, they argued that inasmuch as the Sanitary Corps had more applicants than it could accept, "considerations of patriotism did not warrant his action."

The even course of college affairs continued until April I7, I 865 . And then, the Faculty minutes record:

A Committee consisting of one member from each class waited upon the President stating that on account of their feelings occassioned [sic] by the Assassination of the President of the United States \& by the attempt upon the life of Secretary Seward they were not in a mood to attend properly to their studies, \& therefore asked that they be released from College exercises until after the funeral of President Lincoln on Wednesday April 19th.

The Faculty granted the request of the students requiring, however, that they should be present every morning at the usual Chapel services; \& instructing the President to impress upon their minds the propriety of conducting themselves with due solemnity \& decorum during the week.

On motion, President Campbell was invited to preach in the Chapel next Sabbath, a sermon such as he might deem appropriate to or suggested by the occasion of Mr. Lincoln's death. 
It was also resolved that the College flag be hung at half mast during the week, \& that the College bell be tolled at the hour of Mr. Lincoln's funeral.

A few days later-on April 24-the entire Senior class and a number of other students waited upon President Campbell to request a leave of absence "in order to witness the Celebration of the Obsequies of Mr. Lincoln on Tuesday the 25 inst." in New York City. Again, the faculty viewed with sympathy the students' petition and suspended all classes. And with this tragic event the war, which had seemed so stirring, so exciting, to the students in the Spring of ' $6 \mathrm{I}$, was at last to end.

Twenty-five young men from the classes of the war years had gone off to battle. Joining them in comradeship were fifty-eight alumni of the College, drawn from the classes as far back as I 829. Collectively, they participated in virtually every engagement of the fratricidal war. Sixteen of them-including three who fought under the Stars and Bars--yielded up their lives. A few served humbly in the ranks; most became company or field-grade officers; oneGeorge Henry Sharpe, '47-attained the rank of Major General on Grant's staff.

The College, remote though it seemed from the full impact of the war, showed the effects of the crisis through which the nation was passing as its enrollment dwindled to half the pre-war figure. But actually when the times seemed most desperate, the College was setting forth upon a wholly new course of development. The old ties with the Seminary were severed, the Scientific School was established, the land-grant designation was secured, a successful endowment drive was conducted, and by 1865 what was in many respects a new Rutgers-responsive to the needs of the new age that lay ahead-had emerged.

Death and birth, disaster and achievement-so, as in all times, were opposites linked in the catastrophe that transformed the nation. 